\title{
Przemysław Zdyb*
}

Uniwersytet Szczeciński

\section{DORĘCZENIE ZASTĘPCZE W OGÓLNYM POSTĘPOWANIU ADMINISTRACYJNYM}

\section{Streszczenie}

Niniejszy artykuł poświęcony został problematyce możliwości przyjęcia domniemania prawnego skutecznego doręczania pism w ogólnym postępowaniu administracyjnym, dokonanego w sposób zastępczy w przypadku nieobecności adresata. Analizie poddano przesłanki stawiane przez Kodeks postępowania administracyjnego (k.p.a.) $\mathrm{w}$ art. 43 i 44, od których łącznego spełnienia przepisy prawne uzależniają uznanie doręczenia $\mathrm{w}$ tym trybie za rodzące skutek prawny. $\mathrm{Z}$ jednej strony obowiązujące regulacje mają na celu zapewnienie sprawnego postępowania administracyjnego, a z drugiej - mają zapewnić ochronę praw jednostki przed dowolnością działania organów administracji publicznej. Przedstawione zostało istniejące w tym zakresie orzecznictwo wojewódzkich sądów administracyjnych oraz Naczelnego Sądu Administracyjnego oraz poglądy nauki prezentowane w literaturze przedmiotu.

Słowa kluczowe: postępowanie administracyjne, doręczanie pism

Doręczenia pism w postępowaniu administracyjnym stanowią istotny element prawidłowego działania organów administracji publicznej. Przy ich pomocy organy administracji publicznej uzewnętrzniają treść podejmowanych czynności procesowych, a tym samym umożliwiają zapoznanie się z nimi i ustosunkowanie

*Adres e-mail: pzdyb@mec.univ.szczecin.pl 
się do nich podmiotom biorącym udział w postępowaniu. Normy Kodeksu postępowania administracyjnego regulujące doręczenie stanowią $\mathrm{w}$ istocie gwarancję przestrzegania przez organ administracji publicznej zasady demokratycznego państwa prawnego. Ich celem jest ochrona obywatela, w związku z czym nie mogą być one interpretowane na jego szkodę w sytuacji, gdy ten podejmuje wszelkie starania mające zapewnić mu prawo do wniesienia odwołania (zażalenia) od wydanego przez organ rozstrzygnięcia ${ }^{1}$. Wynikająca z art. 39 k.p.a. zasada oficjalności doręczeń nakłada na organ prowadzący postępowanie administracyjne obowiązek dokonywania wszelkich doręczeń z urzędu. Strony czy inni uczestnicy w tym zakresie nie muszą składać żadnych wniosków ${ }^{2}$. Zasada ta zabezpiecza uprawnienia stron i innych uczestników postępowania, służąc zrównaniu ich pozycji prawnej. Gwarantuje uzyskanie wiedzy o wszelkich czynnościach organu, przez co stwarza możliwość czynnego udziału w postępowaniu. Przepisy prawne zawarte w rozdziale 8 k.p.a. służą realizacji takich zasad ogólnych postępowania administracyjnego, jak: zasada budzenia zaufania uczestników postępowania administracyjnego do władzy publicznej (art. 8 k.p.a.), zasada czuwania przez organ administracji nad interesem strony i innych osób biorących udział w postępowaniu (art. 9 k.p.a.), zasada czynnego udziału strony w postępowaniu (art. 10 k.p.a.), zasada pisemności (art. $14 \S 1$ k.p.a.) ${ }^{3}$, zasada szybkości postępowania (art. 12 k.p.a.) oraz ekonomii procesowej ${ }^{4}$.

\section{Pojęcie doręczenia}

Doręczenie definiowane jest jako czynność procesowa organu administracji publicznej, z którą przepisy Kodeksu wiążą skutki prawne ${ }^{5}$. Szerszą definicję

${ }^{1}$ Tak w uzasadnieniu Wyroku NSA z 30.01.2013 r., sygn. akt II OSK 1817/11; por. również Wyrok NSA z 4.04.2008 r., sygn. akt II GSK 3/08; Wyrok NSA z 6.11.2008 r., sygn. akt II GSK 436/08; Wyrok NSA z 28.04.2009 r., sygn. akt II GSK 887/08. Teksty orzeczeń bez wskazania innego adresu publikatora pochodzą z Centralnej Bazy Orzeczeń Sądów Administracyjnych (CBOSA) dostępnej pod adresem http://orzeczenia.nsa.gov.pl.

${ }^{2}$ G. Łaszczyca, w: G. Łaszczyca, A. Matan, Doręczenie w postępowaniu administracyjnym ogólnym i podatkowym, Kraków 1998, s. 33.

${ }^{3}$ P. Wajda, w: Kodeks postępowania administracyjnego. Komentarz, red. R. Hauser, M. Wierzbowski, Warszawa 2014, s. 182; J. Szuma, w: W. Sawczyn, J. Szuma, Doręczenia w postępowaniu administracyjnym i sadowoadministracyjnym, Wrocław 2014, s. 20-22; M. Wierzbowski, A. Wiktorowska, w: Postępowanie administracyjne - ogólne, podatkowe, egzekucyjne i przed sądami administracyjnymi, red. M. Wierzbowski, Warszawa 2011, s. 25.

${ }^{4}$ G. Łaszczyca, w: G. Łaszczyca, A. Matan, Doręczenie..., s. 32.

${ }^{5}$ A. Wróbel, w: A. Wróbel, M. Jaśkowska, Kodeks postępowania administracyjnego. Komentarz Lex, wyd. 5, Warszawa 2013, s. 356. 
podaje A. Matan wskazując, że doręczenie to wyraźna, władcza, obligatoryjna, formalna i nieodwołalna czynność procesowo-techniczna właściwego organu administracji publicznej lub wykonującego funkcje zlecone, za pomocą której przekazuje się pisma adresatowi w postępowaniu administracyjnym, w sposób prawem przewidziany, z którą to czynnością prawo wiąże określone skutki prawne ${ }^{6}$. J. Borkowski definiuje doręczenie pisma jako czynność materialno-techniczną ${ }^{7}$ powodującą skutki prawne przez fakty (co wynika z natury tej czynności). Jak dalej wskazuje „,zynności materialno-techniczne doręczenia uregulowane w KPA są sformalizowane i to aż do granic kazuistyki unormowań, co jest nieodzowne z uwagi na konieczność ścisłego określenia faktów powodujących skutek prawny. Ścisłe przestrzeganie tych wymagań formalnych należy do obowiązków organu administracyjnego, albowiem od skuteczności doręczenia zależą w wielu przypadkach uprawnienia procesowe lub materialnoprawne stron i innych uczestników postępowania, jak również od daty doręczenia określonych pism ciążyć będą na nich obowiązki, zaniechanie wykonania których może pociągać za sobą zastosowanie środków przymusu administracyjnego, a nawet sankcji karnych"8. W tym kontekście trafnie zauważa A. Błaś, że: „związanie czynności faktycznych normami jedynie kompetencyjnymi nie zapewnia wystarczającej ochrony praw i wolności obywateli. Aby mówić o pełniejszej ochronie tych praw i wolności i aby zabezpieczyć przed samowolnym nakładaniem obowiązków, konieczne jest związane czynności faktycznych normami prawa materialnego i normami prawa procesowego. Nadto musi istnieć możliwość sądowej kontroli czynności faktycz-

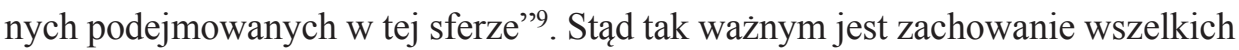
wymogów stawianych doręczeniu, by można je było uznać za skuteczne.

Przedmiotem doręczeń są pisma, przez które rozumieć należy wezwania, zawiadomienia, sporządzoną na piśmie decyzję lub postanowienie ${ }^{10}$. Adresatami pism mogą być osoby fizyczne oraz jednostki organizacyjne i organizacje społeczne mające status strony tego postępowania, ale również występować w nim

${ }^{6}$ A. Matan, w: G. Łaszczyca, C. Martysz, A. Matan, Kodeks postępowania administracyjnego. Komentarz, t. I, Warszawa 2010, s. 428-429.

${ }^{7}$ Czynności materialno-techniczne, obok działań społeczno-realizatorskich, należą do czynności faktycznych, będących jednymi z prawnych form działania administracji. A. Wiktorowska, w: Prawo administracyjne, red. M. Wierzbowski, Warszawa 2011, s. 330-331.

${ }^{8}$ J. Borkowski, w: B. Adamiak, J. Borkowski, Kodeks postępowania administracyjnego. Komentarz, Warszawa 2014, s. 253-255.

${ }^{9}$ A. Błaś, Czynności faktyczne organów administracji publicznej, w: Koncepcja systemu prawa administracyjnego, red. J. Zimmermann, Warszawa 2007, s. 510.

${ }^{10}$ Wyrok WSA w Opolu z 5.06.2014 r., sygn. akt II SA/Op 137/14. 
w charakterze uczestnika na prawach strony, świadka, biegłego czy osób, u których znajduje się przedmiot oględzin. Od chwili doręczenia, zgodnie z art. 110 k.p.a., organ administracji publicznej, który wydał decyzję, jest nią związany, co oznacza, że nie może już jej zmienić dowolnie, ale tylko w sposób i w formach przewidzianych prawem. Ponadto, stosownie do treści art. $129 \S 2$ k.p.a., od daty doręczenia decyzji rozpoczyna bieg termin do wniesienia odwołania ${ }^{11}$. Tak samo dotyczy to chwili związania postanowieniem czy biegu terminu do wniesienia zażalenia (zgodnie z art. 126 oraz 140 k.p.a.).

\section{Podmioty dokonujące doręczeń}

Podmiotami doręczającymi pisma są zgodnie z art. 39 k.p.a. operator pocztowy ${ }^{12} \mathrm{w}$ rozumieniu ustawy z 23 listopada 2012 r. - Prawo pocztowe ${ }^{13}$, pracownicy organu administracji publicznej oraz inne upoważnione osoby lub organy. Jak wskazuje się w piśmiennictwie, przywołany przepis nie ustanawia wiążącej organ kolejności wyboru osoby doręczającej, jednak doręczanie pism przez pracowników organu albo inne upoważnione osoby lub organy powinno być ograniczone tylko do szczególnie uzasadnionych przypadków ${ }^{14}$.

Dodany do Kodeksu postępowania administracyjnego art. $39^{1}$ k.p.a. ${ }^{15}$ przewiduje również możliwość dokonywania przez organ doręczeń za pomocą środków komunikacji elektronicznej ${ }^{16}$. Warunkiem, który musi zostać spełniony, by organ mógł skutecznie doręczać pisma tą drogą, jest konieczność podjęcia przez stronę lub innego uczestnika postępowania stosownego działania: czy to poprzez złożenie podania $\mathrm{w}$ formie dokumentu elektronicznego na elektroniczną

${ }^{11}$ Wyrok NSA z 29.01.2014 r., sygn. akt II OSK 2287/13.

${ }^{12}$ Określana dalej mianem „ustawa - Prawo pocztowe”. Zgodnie z art. 3 pkt 12 tej ustawy operatorem pocztowym jest przedsiębiorca uprawniony do wykonywania działalności pocztowej, na podstawie wpisów do rejestru przedsiębiorców pocztowych.

${ }^{13}$ Dz.U. z 2012 r., poz. 1529.

${ }^{14}$ A. Wróbel, w: A. Wróbel, M. Jaśkowska, Kodeks ..., s. 358.

${ }^{15}$ Przepis dodany Ustawą z 17.01.2005 r. o informatyzacji działalności podmiotów realizujących zadania publiczne (Dz.U. z 2005 r., nr 64, poz. 565 ze zm.).

${ }^{16}$ Zgodnie z art. 2 pkt 5 Ustawy z 18.07.2002 r. o świadczeniu usług drogą elektroniczną (Dz.U. z 2013 r., poz. 1422 ze zm.) przez środki komunikacji elektronicznej należy rozumieć rozwiązania techniczne, w tym urządzenia teleinformatyczne i współpracujące z nimi narzędzia programowe, umożliwiające indywidualne porozumiewanie się na odległość przy wykorzystaniu transmisji danych między systemami teleinformatycznymi, a w szczególności pocztę elektroniczną. 
skrzynkę podawczą organu, wystąpienie do organu z wnioskiem o takie doręczenie, czy wyrażenie zgody na doręczenie pism w postępowaniu za pomocą środków komunikacji elektronicznej. W każdym z tych przypadków strona bądź uczestnik powinien wskazać adres elektroniczny do doręczeń.

\section{Sposoby doręczeń pism w postępowaniu administracyjnym}

Doktryna wyróżnia dwa sposoby doręczeń: doręczenie właściwe oraz doręczenie zastępcze ${ }^{17}$. W świetle przepisów Kodeksu postępowania administracyjnego podstawowym sposobem doręczeń pism osobom fizycznym jest doręczenie właściwe, określane również mianem doręczenia zwykłego ${ }^{18}$ czy bezpośredniego ${ }^{19}$. Polega on na dostarczeniu pisma konkretnej osobie, a zatem - do rąk własnych adresata. Zgodnie $\mathrm{z}$ art. $42 \S 1$ k.p.a., pisma w postępowaniu administracyjnym doręcza się osobom fizycznym w ich mieszkaniu lub miejscu pracy. Pisma mogą być doręczane również w lokalu organu administracji publicznej, a w razie koniecznej potrzeby w każdym miejscu, gdzie się adresata zastanie. Natomiast doręczenie właściwe pism adresowanych do jednostek organizacyjnych i organizacji społecznych następuje w lokalu ich siedziby do rąk osób uprawnionych do odbioru pism (art. 45 k.p.a.).

$\mathrm{Z}$ analizy treści art. 42-45 k.p.a. wynika, że doręczenie właściwe powinno stanowić regułę. Inne dozwolone przypadki doręczeń stanowią wyjątek od powyższej zasady, a zatem przepisy regulujące te kwestie muszą podlegać interpretacji ścisłej.

Doręczenie zastępcze, określane również mianem subsydiarnego, większość autorów ${ }^{20}$ oraz sądów administracyjnych ${ }^{21}$ odnosi zarówno do doręczenia

${ }^{17}$ J. Borkowski, w: B. Adamiak, J. Borkowski, Kodeks postępowania administracyjnego. Komentarz, Warszawa 1996, s. 261. Pogląd ten podziela również G. Łaszczyca, w: G. Łaszczyca, C. Martysz, A. Matan, Kodeks..., s. 454.

${ }^{18}$ R. Kędziora, Kodeks postępowania administracyjnego. Komentarz, Warszawa 2011, s. 290.

${ }^{19}$ Wyrok NSA z 27.08.2014 r., sygn. akt I OSK 720/14.

${ }^{20}$ E. Iserzon, w: E. Iserzon, J. Starościak, Kodeks postępowania administracyjnego. Komentarz, teksty, wzory i formularze, Warszawa 1970, s. 122; Z. Janowicz, Kodeks postępowania administracyjnego. Komentarz, Warszawa-Poznań 1995, s. 132; A. Wróbel, w: A. Wróbel, M. Jaśkowska, Kodeks ..., s. 376; R. Kędziora, Kodeks..., s. 290; A. Krawiec, w: Postępowanie administracyjne, red. T. Woś, wyd. 1, Warszawa 2013, s. 214; P. Wajda, w: Kodeks... red. R. Hauser, M. Wierzbowski, s. 213.

${ }^{21}$ Por. Wyrok WSA w Bydgoszczy z 4.06.2014 r., sygn. akt II SA/Bd 416/14; Wyrok NSA z 8.05.2014 r., sygn. akt II OSK 2934/12; Wyrok NSA z 17.08.2011 r., sygn. akt II GSK 794/10; Wyrok WSA w Szczecinie z 28.11.2013 r., sygn. akt I SA/Sz 484/13. 
opisanego w art. 43 k.p.a. mającego zastosowanie wyłącznie do osób fizycznych, jak również do wskazanego w art. 44 k.p.a. i dotyczącego złożenia pisma dla adresata, będącego osobą fizyczną albo jednostką organizacyjną (organizacją społeczną) w placówce pocztowej albo w urzędzie gminy (art. 45 w zw. z art. 44 k.p.a.). Zdaniem J. Borkowskiego jednak nie jest to zasadne, bowiem doręczenie z art. 44 k.p.a. ma przeciwdziałać tamowaniu postępowania i nakazuje przyjąć skutek doręczenia, nawet gdy faktycznie pismo do adresata nie dotrze. Stąd określa uregulowanie zawarte w tym przepisie mianem doręczenia mieszanego, bowiem „czynności przewidziane przepisem mogą przynieść skutek taki sam, jak doręczenie zastępcze albo spowodują możliwość przyjęcia fikcji doręczenia, co w obu przypadkach usunie przeszkodę w dalszym prowadzeniu postępowania w sprawie"22.

\section{Doręczenie zastępcze z art. 43 k.p.a.}

Przepis art. 43 k.p.a. stosowany jest w wypadku nieobecności adresata w mieszkaniu uniemożliwiającej bezpośrednie doręczenie mu pisma. Instytucja doręczenia zastępczego z art. 43 k.p.a. ma subsydiarny charakter $\mathrm{w}$ relacji do doręczenia właściwego z art. 42 k.p.a. ${ }^{23}$ By organy mogły skorzystać z instytucji doręczenia zastępczego na podstawie art. 43 k.p.a., wcześniej musi dojść do nieskutecznej próby doręczenia pisma adresatowi z art. 42 k.p.a. ${ }^{24} \mathrm{~W}$ przeciwnym razie doręczenie przez organ pisma adresatowi na podstawie normy $z$ art. 43 k.p.a., bez wcześniejszej próby doręczenia na podstawie normy z art. 42 k.p.a., stanowić będzie naruszenie porządku prawnego ${ }^{25}$.

Jak wyraźnie podkreśla się w orzecznictwie, warunkiem skuteczności doręczenia zastępczego jest spełnienie łącznie wszystkich przesłanek przewidzianych w tym przepisie. Po pierwsze, musi wystąpić warunek, aby adresat był nieobecny w domu, i po drugie - pismo można doręczyć tylko dorosłemu domownikowi, sąsiadowi lub dozorcy domu, a osoba ta musi przyjąć pismo osobiście oraz za pokwitowaniem, o ile podjęła się oddania pisma

22 J. Borkowski, w: B. Adamiak, J. Borkowski, Kodeks postępowania administracyjnego. Komentarz, Warszawa 2009, s. 264.

${ }^{23}$ P. Wajda, w: Kodeks..., red. R. Hauser, M. Wierzbowski, s. 206, tak też w Wyroku NSA z 17.07.2013 r., sygn. akt II FSK 2028/12; Postanowienie NSA z 4.04.2013 r., sygn. akt II GSK 426/13.

${ }^{24}$ Wyrok WSA w Kielcach z 15.01.2009 r., sygn. akt I SA/KE 431/08; Wyrok NSA z 28.05.1997 r., sygn. akt I SA/GD 1424/96.

${ }^{25}$ Wyrok WSA w Łodzi z 5.11.2008 r., sygn. akt III SA/ŁD 390/08; Wyrok NSA z 28.03.2007 r., sygn. akt II FSK 453/06. 
adresatowi ${ }^{26}$. Warto tu również wskazać, że formy doręczenia zastępczego pism procesowych odnoszą się tylko do doręczania pism adresatowi w mieszkaniu. Doręczenie pisma osobie fizycznej w jej miejscu pracy może być dokonane wyłącznie do rąk adresata, bowiem przepisy prawa nie przewidują doręczenia zastępczego w miejscu pracy ${ }^{27}$.

Mieszkaniem w rozumieniu art. $42 \S 1$ k.p.a. jest miejsce, w którym adresat przebywa z zamiarem dłuższego (a nie krótkotrwałego) pobytu, umożliwiającego doręczenie mu pisma ${ }^{28}$. Nieobecność adresata oznacza jedynie czasową nieobecność adresata w mieszkaniu niespowodowaną zmianą miejsca zamieszkania czy pobytu ${ }^{29}$. Okoliczność ta musi być każdorazowo znana organowi prowadzącemu postępowanie, aby możliwe było doręczenie przede wszystkim bezpośrednio do rąk adresata. Zapewnieniu tego warunku służy regulacja zawarta w art. $63 \S 2$ k.p.a. ustanawiająca wymóg wskazania swego adresu przez stronę składającą podanie. Art. $41 \S 1$ k.p.a. zobowiązuje z kolei stronę do zawiadamiania organu $\mathrm{w}$ toku postępowania o każdej zmianie swego adresu. W przypadku zaniedbania tego obowiązku doręczenie pisma pod dotychczasowym adresem ma skutek prawny (art. $41 \S 2$ k.p.a.). Jak zauważył Wojewódzki Sąd Administracyjny w Olsztynie, ,zestawienie tych unormowań, przy jednoczesnym braku legalnych definicji użytych w nich pojęć «mieszkanie» i «adres», pozwala przyjąć, że mogą być one traktowane zamiennie i nie muszą być tożsame $\mathrm{z}$ miejscem zameldowania na pobyt stały bądź stałego zamieszkania, gdyż w świetle art. $63 \S 2$ i 41 § 1 k.p.a. adresem strony jest miejsce, gdzie strona faktycznie przebywa i w którym będzie możliwe, zgodnie z jej wolą, doręczenie pism urzędowych do niej adresowanych"30. Organ ma natomiast obowiązek prowadzić postępowanie wyjaśniające w celu ustalenia prawidłowego adresu strony, gdy wszczyna postępowanie z urzędu. Mając na uwadze ustanowioną w art. 7 i 9 k.p.a. zasadę praworządności oraz obowiązek informowania strony przez organ administracji, nie jest dopuszczalne, aby strona postępowania, wszczętego przez organ z urzędu, ponosiła negatywne konsekwencje mające związek z niewyjaśnieniem okoliczności

\footnotetext{
${ }^{26}$ Wyrok NSA z 23.11.2013 r., sygn. akt I OSK 2349/12.

${ }^{27}$ Wyrok NSA z 17.03.2009 r., sygn. akt II OSK 1297/08.

${ }^{28}$ Postanowienie SN z 27.10.2009 r., sygn. akt II UK 81/09.

${ }^{29}$ A. Wróbel, w: A. Wróbel, M. Jaśkowska, Kodeks ..., s. 372.

${ }^{30}$ Wyrok WSA w Olsztynie z 3.12.2013 r., sygn. akt II SA/O1 924/13.
} 
mających znaczenie dla wyboru adresu, na który w sprawie należy dokonywać doręczeń stronie ${ }^{31}$.

Kwestią, nad którą również pochylały się sądy administracyjne, było zagadnienie procedury doręczania pism administracyjnych po dokonaniu przez stronę zmiany adresu do doręczeń. Nie ulega wątpliwości, że strona może żądać doręczania jej korespondencji pochodzącej od organu na dowolny adres. Wskazanie organowi adresu „do doręczeń”, nie będącego adresem miejsca zamieszkania lub pracy powoduje, że dyspozycja art. $42 \S 1 \mathrm{w}$ zw. z art. 43 k.p.a. nie znajdzie zastosowania ${ }^{32}$. W ocenie Naczelnego Sądu Administracyjnego w sytuacji, gdy strona postępowania administracyjnego wskazuje adres do doręczeń, który jest inny niż jej adres zamieszkania, to należy przyjąć, że wszystkie dorosłe osoby zamieszkujące pod wskazanym adresem do doręczeń są upoważnione do odbioru korespondencji kierowanej przez organ na ten adres. Przepis art. 43 k.p.a. nie ma zastosowania w przypadku doręczenia pisma na wskazany przez stronę adres do doręczeń, gdyż doręczenie zastępcze pism w trybie art. 43 k.p.a. odnosi się tylko do doręczania pism adresatowi we wskazanym przez niego miejscu zamieszkania. Twierdzenie, że osoba, która zamieszkuje pod adresem wskazanym przez stronę jako adres do doręczeń, nie jest dorosłym domownikiem w rozumieniu art. 43 k.p.a., w przypadku, gdy sama strona podaje inny adres zamieszkania, jest samo w sobie sprzeczne, jak również nieuprawnione w świetle art. 43 k.p.a. ${ }^{33}$

W orzecznictwie i literaturze przedmiotu status ,domownika” jest oceniany niejednolicie. W niektórych wyrokach NSA przypisuje taki status zamieszkującym $\mathrm{z}$ adresatem $\mathrm{w}$ jednym mieszkaniu lub domu jego dorosłym krewnym i powinowatym ${ }^{34}$. Oznacza to, że nie każdą pełnoletnią osobę spokrewnioną z adresatem można uznać za dorosłego domownika, któremu można oddać przesyłkę przeznaczoną dla określonej osoby. Warunkiem koniecznym jest, aby osoba spokrewniona z adresatem pisma zamieszkiwała pod wskazanym adresem, nawet jeżeli nie jest tam zameldowana. Natomiast osoby obce adresatowi nie są jego domownikami nawet, gdy mieszkają w tym samym domu lub mieszkaniu (np. jako lokatorzy), chyba że zostały przez adresata włączone do wspólnoty

${ }^{31}$ Wyrok NSA z 9.04.2014 r., sygn. akt I OSK 2341/12.

${ }^{32}$ Wyrok NSA z 20.02.2014 r., sygn. akt II OSK 2159/12.

${ }^{33}$ Wyrok NSA z 24.01.2014 r., sygn. akt II OSK 2017/12.

${ }^{34}$ Wyrok NSA z 9.09.2011 r., sygn. akt II OSK 1333/10; A. Wróbel, w: A. Wróbel, M. Jaśkowska, Kodeks ..., s. 373. 
domowej i prowadzą z nim (jego rodziną) wspólne gospodarstwo domowe ${ }^{35}$. W innych orzeczeniach sądy wskazują, że, ,językowe brzmienie pojęcia «domownik» wskazuje właśnie, że będzie to stały mieszkaniec lokalu lub domu, człowiek razem z adresatem mieszkający, np. członek rodziny, współlokator, pracownik domowy" ${ }^{36}$. Stąd też P. Wajda wskazuje, że z uwagi na rozbieżności w orzecznictwie, jak też ,charakter i dynamikę zachodzących procesów społecznych, które niejednokrotnie znacząco wyprzedzają prawodawstwo, należałoby opowiedzieć się za każdorazowym określaniem desygnatów pojęcia dorosły domownik na gruncie konkretnego przypadku w ramach danej sprawy administracyjnej, co miałoby odbywać się przy równoczesnym zastosowaniu ogólnych kryteriów klasyfikacji wynikających z przytoczonych powyżej orzeczeń" ${ }^{37}$.

Pojęcie „dorosłego” także nie zostało w art. 43 k.p.a. zdefiniowane. W orzecznictwie i doktrynie zgodnie jednak przyjmuje się, że termin „dorosły” w rozumieniu art. 43 k.p.a. oznacza to samo, co ,pełnoletni” użyty w art. 10 k.c. ${ }^{38}$ Uregulowanie to ma na celu zagwarantowanie stronie postępowania administracyjnego, że korespondencja kierowana na jej imię i nazwisko dotrze do jej wiadomości. Należy uznać zatem za całkowicie zrozumiałe, że doręczenia pisma stronie może się podjąć wyłącznie osoba pełnoletnia, czyli taka, która nabyła pełnię praw publicznych, a tym samym ponosi całkowitą odpowiedzialność za swoje czyny ${ }^{39}$. Doręczenie pisma domownikowi małoletniemu nie jest prawnie skuteczne ${ }^{40}$. W przypadku odebrania korespondencji przez osobę niepełnoletnią, strona postępowania administracyjnego może w celu obrony własnych interesów skutecznie podnieść zarzut wadliwego doręczenia korespondencji w tym trybie i obalić domniemanie doręczenia zastępczego ${ }^{41}$. W orzecznictwie i w doktrynie zwraca się uwagę, że w sytuacji, kiedy doręczenie - niezgodnie z wymogami art. 43 k.p.a. dokonane zostało do rąk niepełnoletniego domownika, ale domownik ten nie-

${ }^{35}$ Wyrok NSA z 27.08.2014 r., sygn. akt I OSK 720/14.

${ }^{36}$ Wyrok NSA z 26.01.2010 r., sygn. Akt I OSK 159/09.

${ }^{37}$ P. Wajda, w: Kodeks..., red. R. Hauser, M. Wierzbowski, s. 209.

${ }^{38}$ Postanowienie NSA, Ośrodek Zamiejscowy w Poznaniu z 3.12.1993 r., sygn. akt SA/Po 1931/1993; Wyrok NSA z 17.05. 1999 r., sygn. akt II SA 447/1999.

${ }^{39}$ Postanowienie NSA z 15.11.2013 r., sygn. akt I OZ 1082/13.

${ }^{40}$ P. Wajda, Kodeks ..., red. R. Hauser, M. Wierzbowski, s. 207.

${ }^{41}$ Wyrok NSA z 5.11.2010 r., sygn. akt II GSK 948/09; Wyrok NSA z 8.02.2011 r., sygn. akt I OSK 1749/10; Wyrok WSA w Opolu z 26.05.2011 r., sygn. akt II SA/OP 129/11; a także J. Borkowski, Doręczenia, w: B. Adamiak, J. Borkowski, Kodeks..., Warszawa 2009, s. 244; L. Żukowski, R. Sawuła, Postępowanie administracyjne, Warszawa 2002, s. 77. 
zwłocznie przekazał pismo adresatowi, a sam adresat nie kwestionuje faktu terminowego doręczenia, nawet wprost to potwierdza, a co więcej - strona w ustawowym terminie dokona czynności (wniesienie odwołanie, złoży skargę), uznać należy, że uchybienie procedurze doręczenia zastępczego nie miało wpływu na skuteczność doręczenia. ${ }^{42}$ Należy zwrócić uwagę, że doręczający winien sprawdzać, czy odbiorca przesyłki faktycznie ukończył 18 lat i jest tym samym uprawniony do jej odbioru w imieniu adresata. Stosownie do art. 112 k.c. zdanie drugie, przy obliczaniu wieku osoby fizycznej termin upływa z początkiem ostatniego dnia, który swoją datą odpowiada dniu urodzenia.

Za sąsiada uznaje się osobę, która mieszka w pobliżu adresata, na terenie graniczącym z jego terenem. W każdym konkretnym przypadku podmiot doręczający musi zatem uwzględnić specyfikę zamieszkania adresata. Sąsiadem może być osoba mieszkająca w tym samym budynku czy też w budynku będącym w najbliższym otoczeniu domu adresata ${ }^{43}$. Odebranie przesyłki przez osobę przebywającą w domu adresata, lecz zamieszkującą pod innym adresem należy traktować jako zobowiązanie się do oddania pisma adresatowi jako „sąsiad”, a dla skuteczności takiego doręczenia wymagane jest pozostawienie zawiadomienia $\mathrm{u}$ adresata poprzez umieszczenie zawiadomienia w oddawczej skrzynce pocztowej, lub gdy to nie jest możliwe, w drzwiach mieszkania (art. 43 zd. drugie k.p.a.) ${ }^{44}$. Dozorca domu oznacza natomiast osobę, której zlecono pilnowanie, doglądanie domu, przy czym czynności te wykonywane są w sposób ciągły ${ }^{45}$. Do grona takich osób zalicza się ochroniarzy, zarządców nieruchomości, recepcjonistów, konserwatorów ${ }^{46}$.

Kolejnymi przesłankami, które muszą zostać spełnione, by doręczenie zastępcze uznane być mogło za skuteczne, jest dobrowolne podjęcie się oddania pisma adresatowi przez odbierającego i dokonanie pokwitowania. W orzecznictwie wskazuje się, że norma prawna zawarta w przepisie art. 43 k.p.a. nie

42 Tak w postanowieniu NSA z 7.08.2009 r., sygn. akt I OSK 995/09; Wyrok NSA z 5.11.2010 r., sygn. akt II GSK 948/09; Wyrok NSA z 8.02.2011 r., sygn. akt I OSK 1750/10; Wyrok NSA z 1.12. 2011 r., sygn. akt II FSK 1424/10; Wyrok WSA w Warszawie z 18.10.2012 r., sygn. akt II SA/ WA 1383/12; Wyrok WSA w Gliwicach z 3.06.2015 r., sygn. akt I SA/G1 1135/14 oraz B. Dauter, B. Gruszczyński, A. Kabat, M. Niezgódka-Medek, Prawo o postępowaniu przed sąami administracyjnymi. Komentarz, Kraków 2006, s.183.

\footnotetext{
${ }^{43}$ G. Łaszczyca, w: G. Łaszczyca, C. Martysz, A. Matan, Kodeks..., s. 451.

44 Wyrok NSA z 5.10.2007 r., sygn. akt II OSK 1109/06.

45 G. Łaszczyca, w: G. Łaszczyca, C. Martysz, A. Matan, Kodeks..., s. 451.

${ }^{46}$ P. Wajda, w: Kodeks..., red. R. Hauser, M. Wierzbowski, s. 209.
} 
wymaga, aby „podjęcie się oddania pisma adresatowi” miało formułę wyraźnego oświadczenia, z którego treści wynika zgoda odbiorcy na przyjęcie pisma i zobowiązanie do osobistego oddania go adresatowi. Dla skutecznego doręczenia pisma wystarczy, aby na podpisywanym przez domownika potwierdzeniu odbioru pisma znajdowała się informacja, że doręczenie następuje, jeżeli osoba ta podjęła się oddania pisma adresatowi. Określony w art. 43 k.p.a. sposób doręczenia zastępczego pisma opiera się bowiem na domniemaniu, że osoba wskazana na potwierdzeniu odbioru jako domownik adresata, kwitująca odbiór pisma, przyjęła je w celu oddania adresatowi oraz że pismo to zostało mu doręczone ${ }^{47}$. Pokwitowanie złożone przez dorosłego domownika na dowodzie doręczenia jest następstwem aktu woli, jakim jest podjęcie się przez tę osobę oddania adresatowi pisma. Stanowi ono uzewnętrznienie podjętej wcześniej przez odbierającego pismo woli przekazania przesyłki adresatowi ${ }^{48}$. Jeżeli na odwrocie poświadczenia odbioru pisma nie podkreślono, że doręczenia dokonano dorosłemu domownikowi, zaznaczając lub wskazując jednocześnie, że osoba ta podjęła się oddać przesyłkę adresatowi, to doręczenie nie spełnia wymogów z art. $40 \S 1$ ani z art. 43 k.p.a. ${ }^{49}$

Zgodnie z art. 46 k.p.a., osoba odbierająca pismo powinna złożyć swój podpis i wskazać datę doręczenia. W przypadku doręczenia zastępczego w treści pokwitowania należy wskazać, kim jest osoba, która odebrała pismo zamiast adresata $^{50}$. Samodzielne stwierdzenie przez doręczyciela daty odbioru oraz wskazanie osoby, która odebrała pismo, może mieć miejsce w przypadku, gdy odbierający nie może się podpisać. W tej sytuacji doręczający jest obowiązany wskazać osobę, która odebrała pismo, co polega na podaniu imienia i nazwiska tej osoby oraz określeniu, czy jest to adresat czy też jego dorosły domownik albo sąsiad lub dozorca domu (stosownie do art. 43 k.p.a.). Wówczas dodatkowo doręczający wskazuje przyczynę braku podpisu ${ }^{51}$.

Jeżeli pismo doręczono sąsiadowi lub dozorcy, to zawiadamia się o tym adresata umieszczając zawiadomienie w oddawczej skrzynce pocztowej lub, gdy to nie jest możliwe, w drzwiach mieszkania. Brak takiego zawiadomienia powo-

${ }^{47}$ Wyrok NSA z 8.11.2007 r., sygn. akt II GSK 192/07; Wyrok NSA z 17.11.2009 r., sygn. akt II GSK 208/09; Wyrok NSA z 18.01.2012, sygn. akt II OSK 2070/10.

${ }^{48}$ Wyrok NSA z 23.09.2009 r., sygn. akt II GSK 60/09.

49 Postanowienie NSA z 20.05.2014 r., sygn. akt I OSK 1099/14.

${ }^{50}$ Wyrok NSA z 14.03.2007 r., sygn. akt II GSK 315/06; Postanowienie NSA z 23.09.2014 r., sygn. akt II GSK 2120/14.

${ }^{51}$ Wyrok WSA w Szczecinie z 23.10.2013 r., sygn. akt II SA/Sz 554/13. 
duje nieskuteczność doręczenia pisma ${ }^{52}$. Nie pozostawia się jednak zawiadomienia, gdy pismo doręczono dorosłemu domownikowi.

Przewidziana $\mathrm{w}$ art. 43 k.p.a. zastępcza forma doręczenia pisma rodzi domniemanie prawne (praesumptio iuris), że pismo zostało doręczone adresatowi ${ }^{53}$. Domniemanie to powstaje tylko wtedy, gdy pewny jest fakt, iż pismo to zostało doręczone jednej z osób wymienionych w przepisie z art. 43 k.p.a. Od daty doręczenia zastępczego rozpoczyna się bieg terminu do wniesienia odwołania (zażalenia, zarzutów), gdyż pokwitowanie odbioru decyzji (postanowienia, tytułu wykonawczego) przez osobę w tym trybie uznaje się jako doręczenie jej adresatowi. Domniemanie to może zostać obalone, gdy adresat udowodni, że pomimo zastosowania zastępczej formy doręczenia pismo nie zostało mu doręczone z przyczyn od niego niezależnych. Do takich przyczyn można m.in. zaliczyć takie okoliczności, jak niewywiązanie się dorosłego domownika, sąsiada lub dozorcy z przyjętego zobowiązania doręczenia pisma adresatowi, pozostawanie adresata przez dłuższy czas w podróży poza miejscem zamieszkania $^{54}$. Należy jednak pamiętać, że jeśli osoba, do rąk której dokonano doręczenia zastępczego nie powiadomiła adresata o decyzji (postanowieniu, tytule wykonawczym) w terminie do wniesienia odwołania (zażalenia, zarzutów), to zaniechanie tej osoby wywołuje skutki dla adresata rozstrzygnięcia i nie stanowi okoliczności uprawdopodobniającej, że uchybienie terminowi do wniesienia odwołania przez adresata nastąpiło bez jego winy ${ }^{55}$. Kwestionowanie domniemania doręczenia zastępczego może dotyczyć zarówno sytuacji, gdy wadliwość doręczenia jest widoczna już na tle treści samego pokwitowania, jak też odmiennej kwestii, jaką jest prowadzenie postępowania wyjaśniającego mającego służyć udowodnieniu nieskuteczności doręczenia stwierdzonego pokwitowaniem, którego treść nie nasuwa żadnych zastrzeżeń, zaś adresat, przecząc okolicznościom, jakie ono stwierdza, zmierza do obalenia domniemania skuteczności doręczenia. Prawidłowe pokwitowanie (potwierdzenie) odbioru przesyłki stwarza jedynie

${ }^{52}$ Wyrok NSA z 23.09.2009 r., sygn. akt I OSK 1359/08; Wyrok WSA w Warszawie z 20.11.2012 r., sygn. akt I SA/Wa 1868/12.

${ }_{53}$ P. Wajda, w: Kodeks..., red. R. Hauser, M. Wierzbowski, s. 212; Wyrok WSA w Krakowie z 29.03.2011 r., sygn. akt II SA/Kr 1491/10.

${ }^{54}$ Zob. Wyrok WSA w Warszawie z 7.05.2007 r., sygn. akt I SA/Wa 56/07; Wyrok NSA z 16.11.2010 r., sygn. akt II OSK 1754/09.

${ }^{55}$ Wyrok WSA w Białymstoku z 18.06.2013 r., sygn. akt I SA/Bk 159/13; Wyrok WSA w Gorzowie Wielkopolskim z 4.07.2013 r., sygn. akt II SA/Go 446/13; Wyrok WSA w Poznaniu z 21.08.2013 r., sygn. akt III SA/Po 346/13. 
domniemanie doręczenia, które może być jednak obalone przeciwdowodem. Dokument doręczenia nie stanowi wyłącznego dowodu na okoliczności w nim zawarte. Również w razie wątpliwości samego organu, czy okoliczności zawarte w dowodzie doręczenia odpowiadają rzeczywistości, koniecznym jest podjęcie z urzędu właściwych czynności sprawdzających i przeprowadzenie wszelkich potrzebnych dowodów ${ }^{56}$.

\section{Doręczenie z art. 44 k.p.a.}

Zasadą w postępowaniu administracyjnym jest doręczenie pisma organu do rąk adresata, będącego osobą fizyczną (art. 42 k.p.a.). Możliwe jest także doręczenie, o którym mowa w art. 44 k.p.a. - tak zwane doręczenie zastępcze stwarzające domniemanie prawne (praesumptio iuris) doręczenia (tzw. fikcja prawna doręczenia), przy czym zasady jego stosowania muszą być stosowane ściśle i uchybienie któremukolwiek z elementów procedury doręczenia zastępczego powoduje, że organ nie może skutecznie się powołać na domniemanie doręczenia $^{57}$. Domniemanie to nie ma również zastosowania w przypadku pisma błędnie zaadresowanego ${ }^{58}$.

Pierwszą przesłanką skuteczności doręczenia określonego w art. 44 § 1 k.p.a. jest niemożność doręczenia pisma w sposób wskazany w art. 42 i 43 k.p.a. oraz w art. 45 k.p.a. na podstawie odesłania zawartego w tym przepisie. Niemożność ta obejmuje sytuacje, w których adresatowi będącemu osobą fizyczną nie doręczono pisma w żadnym z miejsc przewidzianych w art. 42 k.p.a., nie doręczono pisma żadnej z osób wymienionych w art. 43 k.p.a. bądź też nie doręczono pisma osobie uprawnionej w lokalu siedziby jednostki organizacyjnej lub organizacji społecznej (art. 45 k.p.a.). Należy przyjąć, że niemożność doręczenia w sposób wskazany w art. 42 k.p.a. dotyczy przypadków, w których podmiot doręczający nie zastał adresata pisma. Niemożność doręczenia zaś w sposób wskazany w art. 43 k.p.a. obejmuje zarówno sytuacje, w których doręczający nie zastał dorosłego domownika strony, jego sąsiada lub dozorcy, lecz także sytuacje, w których te osoby nie podjęły się oddania pisma adresatowi ${ }^{59}$.

${ }^{56}$ Wyrok WSA w Krakowie z 30.01.2013 r., sygn. akt II SA/Kr 1506/12.

${ }^{57}$ Wyrok NSA z 30.12.2013 r., sygn. akt I OSK 317/12.

${ }^{58}$ Wyrok NSA z 29.03.2012 r., sygn. akt I OSK 1233/11.

${ }^{59}$ A. Wróbel, w: A. Wróbel, M. Jaśkowska, Kodeks..., s. 376; por. także Wyrok WSA w Warszawie z 6.01.2012 r., sygn. akt I SA/Wa 2104/11. 
Drugą przesłanką jest przechowywanie pisma przez okres 14 dni w placówce operatora pocztowego ${ }^{60}$ (gdy pismo doręczane jest przez tego operatora) albo w urzędzie właściwej gminy (miasta) w przypadku doręczenia pisma przez pracownika urzędu gminy (miasta) lub upoważnioną osobę lub organ. Trzecią przesłanką dla uznania prawidłowości doręczenia (art. 44 § 2 k.p.a.) jest umieszczenie zawiadomienia o pozostawieniu pisma wraz informacją o możliwości jego odbioru w terminie 7 dni w placówce operatora pocztowego. Przepis ten ustanawia wiążącą doręczyciela kolejność miejsc, w których należy umieścić zawiadomienie: najpierw w oddawczej skrzynce pocztowej, następnie na drzwiach mieszkania adresata, jego biura lub innego pomieszczenia, w których adresat wykonuje swoje czynności zawodowe, a w ostateczności - w widocznym miejscu przy wejściu na posesję adresata ${ }^{61}$. Zgodnie z dyspozycją art. $44 \S 3$ k.p.a. w przypadku niepodjęcia przesyłki $\mathrm{w}$ terminie wskazanym $\mathrm{w} \S 2$, pozostawia się powtórne zawiadomienie o możliwości odbioru przesyłki w terminie nie dłuższym niż 14 dni od daty pierwszego zawiadomienia. W wyroku z 16.02.2012 r. NSA ${ }^{62}$ wskazał, że nawet gdy powtórne zawiadomienie o możliwości odbioru przesyłki pozostawione zostało o jeden dzień wcześniej, to jednak wobec tego, że od daty pierwszego awiza (zawiadomienia) do dnia zwrotu do nadawcy upłynęło pełne 14 dni, to bez znaczenia jest fakt, że drugie awizowanie zostało dokonane przedwcześnie.

Dopiero po spełnieniu wszystkich powyższych warunków, na mocy art. $44 \S 4$ k.p.a., doręczenie uznaje się za dokonane z upływem czternastu dni od dnia pierwszego zawiadomienia, a pismo pozostawia się w aktach sprawy. Nie ma nawet na to wpływu sytuacja, w której adresat odbierze pismo na przykład piętnastego czy szesnastego dnia z placówki pocztowej, zanim nastąpi odesłanie pisma do nadawcy ${ }^{63}$. Jeśli adresat odbierze pismo przed upływem tego terminu z placówki pocztowej czy urzędu gminy, to za datę doręczenia należy przyjąć dzień odbioru pisma ${ }^{64}$.

${ }^{60}$ Przez placówkę operatora pocztowego, zgodnie z art. 3 pkt 15 ustawy - Prawo pocztowe, należy rozumieć jednostkę organizacyjną operatora pocztowego lub agenta pocztowego, w której można zawrzeć umowę o świadczenie usługi pocztowej lub która doręcza adresatom przesyłki pocztowe lub kwoty pieniężne określone w przekazach pocztowych, albo inne wyodrębnione i oznaczone przez operatora pocztowego miejsce, w którym można zawrzeć umowę o świadczenie usługi pocztowej lub odebrać przesyłkę pocztową lub kwotę pieniężną określoną w przekazie pocztowym.

${ }^{61}$ Wyrok WSA w Łodzi z 23.10.2014 r., sygn. akt III SA/Łd 584/14.

${ }^{62}$ Wyrok NSA z 16.02.2012 r., sygn. akt I OSK 1944/11.

${ }^{63}$ Postanowienie NSA z 12.01.2012 r., sygn. akt II FSK 2916/11; Wyrok NSA z 17.07.2013 r., sygn. akt II FSK 2028/12.

${ }^{64}$ R. Kędziora, Kodeks..., s. 298; P. Wajda, w: Kodeks..., s. 219. 
Warunkiem uznania pisma za doręczone jest spełnienie wszystkich wymogów płynących z przepisu art. 44 k.p.a. Musi też istnieć pewność co do tego, że nastąpiło prawidłowe zawiadomienie adresata o pozostawieniu przesyłki w oddawczym urzędzie pocztowym przez określony czas. Adresat powinien być zawiadomiony zarówno o pozostawieniu pisma, jak i miejscu, skąd może je odebrać i o terminie odbioru, a zwrotne potwierdzenie odbioru powinno być wypełnione czytelnie wraz z podpisem osoby doręczającej pismo. Jak wskazuje się w orzecznictwie, w świetle art. $44 \S 4$ k.p.a., ocena ziszczenia się skutku prawnego polegającego na uznaniu pisma za doręczone nie może być sformułowana wyłącznie w oparciu o stwierdzenie, iż pismo było przechowywane przez pocztę przez okres czternastu dni w jej placówce, lecz musi być powiązana także z ustaleniem, że w czasie biegu tego terminu zostały spełnione wszystkie pozostałe wymogi z art. 44 § 2 i 3 k.p.a. ${ }^{65}$ Samo zamieszczenie na kopercie zawierającej przesyłkę lub na dowodzie potwierdzającym doręczenie pisma pieczęci operatora pocztowego i daty czy wzmianki o awizowaniu przesyłki, nie może być wystarczające do przyjęcia, że spełnione zostały przesłanki doręczenia ustanowione w art. 44 k.p.a. Bezwarunkowo konieczna jest adnotacja doręczyciela, że zawiadomił adresata o przesyłce w sposób przewidziany prawem ${ }^{66}$. Podkreślić należy, że jeśli doręczenie decyzji nastąpiło w drodze tzw. doręczenia zastępczego wskazanego w art. 44 k.p.a., to skutek takiego doręczenia nastąpił, i nawet późniejsze, kolejne już w danej sprawie, doręczenie rozstrzygnięcia organu nie powoduje otwarcia dla strony na nowo terminu do zaskarżenia tego rozstrzygnięcia. Należy mu zaś przypisać jedynie walor informacyjny ${ }^{67}$. Domniemanie prawne, że pismo zostało doręczone adresatowi, może zostać obalone, gdy adresat udowodni, że mimo zastosowania zastępczej formy doręczenia pismo nie zostało mu doręczone z przyczyn od niego niezależnych. Ciężar obalenia domniemania spoczywa jednak na stronie ${ }^{68}$.

W wyroku z 31.05.2012 r. NSA ${ }^{69}$ wyjaśnił, że procesowa instytucja doręczenia zastępczego polega nie tyle na domniemaniu, ile oparta jest na konstrukcji

${ }^{65}$ Wyrok NSA z 4.12.2012 r., sygn. akt II OSK 1367/11; Wyrok NSA z 30.12.2013 r., sygn. akt I OSK 316/12.

${ }^{66}$ Tak m.in. w: Wyrok NSA z 17.12.2008 r., sygn. akt II OSK 523/07; Postanowienie NSA z 23.04.2009 r., sygn. akt I OSK 405/09; Postanowienie NSA z 24.06.2009 r., sygn. akt I OZ 642/09; Postanowienie NSA z 9.02.2010 r., sygn. akt II GSK 1087/09; Wyrok NSA z 22.02.2012 r., sygn. akt II OSK 2329/10; Wyrok NSA z 19.06.2013 r., sygn. akt I OSK 406/13.

${ }^{67}$ Wyrok WSA w Rzeszowie z 12.06.2013 r., sygn. akt II SA/Rz 174/13.

${ }^{68}$ Wyrok NSA z 1.02.2011 r., sygn. akt II OSK 1098/10.

${ }^{69}$ Wyrok NSA z 31.05.2012 r., sygn. akt I OSK 2105/11. 
fikcji prawnej poprzez uznanie, że nastąpiło doręczenie pisma, które de facto nie miało miejsca. Jednak warunkiem przyjęcia przez organ takiej fikcji prawnej, tj. uznania, iż nastąpiło doręczenie zastępcze, jest dysponowanie przez ten organ niebudzącym wątpliwości dowodem potwierdzającym, że przesłanki określone w art. 44 k.p.a. zostały spełnione. Takim dowodem dla organu nie jest wykazanie przez stronę, że nie otrzymała awiza, ale zwrotne potwierdzenie odbioru zawierające pełną informację, że adresat został zawiadomiony zarówno o pozostawieniu pisma, jak i o miejscu oraz terminie $\mathrm{z}$ datą i podpisem doręczyciela.

W wyroku z dnia 10.04.2002 NSA wskazał, iż „nie ma wątpliwości, że prawidłowo dokonane zastępcze doręczenie jest równoważne w skutkach z doręczeniem, gdzie dokument doręczany rzeczywiście trafia do rąk adresata tak, aby ten mógł się z nim zapoznać. Doręczenie zastępcze jest klasyczną fikcją niewątpliwie mającą rację bytu z punktu widzenia sprawności obrotu. Jednakże fikcja ta jest tylko o tyle zasadna, że u jej podstawy spoczywa założenie, iż co do samej zasady adresat może uzyskać dokument doręczony zastępczo i może się z nim zapoznać, jednakowoż z przyczyn leżących po jego stronie tego nie czyni"70. W sytuacji, w której doręczenie nastąpiło niezgodnie z obowiązującymi przepisami, należy traktować je jako bezskuteczne, co oznacza, że termin do dokonania czynności nie rozpoczyna biegu. Strona nie musi więc składać wniosku o przywrócenia terminu, a jeżeli to uczyni, wniosek jest bezprzedmiotowy ${ }^{71}$. Jak trafnie ujmuje to G. Łaszczyca, doręczenie niezgodne z przepisami k.p.a. nie ma skutku prawnego, przez co nie zachodzi potrzeba stwierdzenia nieważności tej czynności, „tym bardziej, że k.p.a. nie przewiduje żadnej procedury służącej do eliminowania wadliwych czynności materialno-technicznych. Bezskuteczność czynności procesowej doręczenia prowadzi do obowiązku ponownego jej dokonania, a zatem powtórzenia tej czynności zgodnie z obowiązującymi przepisami prawa"72.

Czyniąc na koniec konkluzje do powyżej przedstawionych wywodów, podkreślić raz jeszcze należy doniosłość znaczenia skutecznego doręczenia pism w postępowaniu administracyjnym. Normy zawarte w całym rozdziale 8 Kodeksu postępowania administracyjnego dotyczącym doręczeń, w tym również w art. 43 i 44 k.p.a., z uwagi na ich ogólny cel stanowią w istocie gwarancje przestrzegania przez organ administracji publicznej zasady demokratycznego państwa

${ }^{70}$ Wyrok NSA z 10.04.2001 r., sygn. akt V SA 2002/00.

${ }^{71}$ Wyrok WSA w Łodzi z 6.05.2009 r., sygn. akt III SA/Łd 12/09; Wyrok WSA w Poznaniu z 11.09.2013 r., sygn. akt IV SA/Po 606/13.

${ }^{72}$ G. Łaszczyca, w: G. Łaszczyca, A. Matan, Doręczenie..., s. 30. 
prawnego. Regulacje te mają chronić przed nadużyciami ze strony administracji i równocześnie zapewnić sprawny przebieg postępowania. Każda sytuacja naruszenia przez organ obowiązków doręczenia pisma adresatowi (a w szczególności doręczenia stronie decyzji czy postanowienia), która prowadzić może do obalenia domniemania skutecznego doręczenia, powinna być oceniana indywidualnie, z uwzględnieniem okoliczności danej sprawy oraz ewentualnych skutków procesowych dla podmiotu będącego adresatem decyzji, które to skutki spowodowane zostały nieprawidłowym doręczeniem pisma.

\section{Literatura}

Błaś A., Czynności faktyczne organów administracji publicznej, w: Koncepcja systemu prawa administracyjnego, red. J. Zimmermann, Warszawa 2007.

Borkowski J., w: B. Adamiak, J. Borkowski, Kodeks postępowania administracyjnego. Komentarz, Warszawa 1996.

Borkowski J., w: B. Adamiak, J. Borkowski, Kodeks postępowania administracyjnego. Komentarz, Warszawa 2009.

Dauter B., Gruszczyński B., Kabat A., Niezgódka-Medek M., Prawo o postępowaniu przed sądami administracyjnymi. Komentarz, Kraków 2006.

Iserzon E., w: E. Iserzon, J. Starościak, Kodeks postępowania administracyjnego. Komentarz, teksty, wzory i formularze, Warszawa 1970.

Janowicz Z., Kodeks postępowania administracyjnego. Komentarz, Warszawa-Poznań 1995.

Kędziora R., Kodeks postępowania administracyjnego. Komentarz, Warszawa 2011.

Krawiec A., w: Postępowanie administracyjne, red. T. Woś, wyd. 1, Warszawa 2013.

Łaszczyca G., Matan A., Doręczenie w postępowaniu administracyjnym ogólnym i podatkowym, Kraków 1998.

Matan A., w: G. Łaszczyca, C. Martysz, A. Matan, Kodeks postepowania administracyjnego. Komentarz, t. I, Warszawa 2010.

Szuma J., w: W. Sawczyn, J. Szuma, Doręczenia w postepowaniu administracyjnym i sqdowoadministracyjnym, Wrocław 2014.

Wajda P., w: Kodeks postępowania administracyjnego. Komentarz, red. R. Hauser, M. Wierzbowski, Warszawa 2014.

Wierzbowski M., Wiktorowska A., w: Postępowanie administracyjne - ogólne, podatkowe, egzekucyjne i przed sądami administracyjnymi, red. M. Wierzbowski, Warszawa 2011.

Wiktorowska A., w: Prawo administracyjne, red. M. Wierzbowski, Warszawa 2011. 
Wróbel A., w: A. Wróbel, M. Jaśkowska, Kodeks postępowania administracyjnego. Komentarz Lex, wyd. 5, Warszawa 2013.

\section{Źródła prawa}

Ustawa z 18.07.2002 r. o świadczeniu usług drogą elektroniczną (Dz.U. z 2013 r., poz. 1422 ze zm.)

Ustawa z 17.01.2005 r. o informatyzacji działalności podmiotów realizujących zadania publiczne (Dz.U. z 2005 r., nr 64, poz. 565 ze zm.).

Ustawa z 23.11.2012 r. - Prawo pocztowe (Dz.U. z 2012 r., poz. 1529).

\section{SUBSTITUTE SERVICE GENERAL ADMINISTRATIVE}

\section{Summary}

This article is devoted to the issues of the acceptability of a legal presumption of effective serve of documents in the general administrative procedure made in the manner substitute in case of the absence of the addressee. Analysis covered the conditions imposed by the Code of Administrative Proceedings in article 43 and 44 of which the total compliance of the legislation make the classification of service in this mode, the emerging legal effect. On the one hand the current regulations are designed to ensure a efficient administrative proceedings, and on the other to protect the rights of the individuals against arbitrariness actions of public administration. In the article presented the existing case law in this area of provincial administrative courts and the Supreme Administrative Court and the views of modern science administrative proceedings law presented in the literature.

Translated by Przemystaw Zdyb

Keywords: administrative procedure, service of documents 